\title{
Dadaism: Restrictivism as Militant Quietism
}

Tim Button

February 12, 2010

\begin{abstract}
Can we quantify over everything: absolutely, positively, definitely, totally, every thing? Some philosophers have claimed that we must be able to do so, since the doctrine that we cannot is self-stultifying. But this treats restrictivism as a positive doctrine. Restrictivism is much better viewed as a kind of militant quietism, which I call dadaism. Dadaists advance a hostile challenge, with the aim of silencing everyone who claims to hold a positive position about 'absolute generality'.
\end{abstract}

Copyright notice. This paper is due to appear in Proceedings of the Aristotelian Society. This is a pre-print, and may be subject to minor changes. The authoritative version should be obtained from Proceedings of the Aristotelian Society, once it has been published.

Can we quantify over everything: absolutely, positively, definitely, totally, every thing? Some philosophers have claimed that we must be able to do so, since to claim otherwise is self-contradictory. I want to contest this line of argument.

I start by motivating restrictivism (s[M). I then explain the charge that restrictivism is self-stultifying. The problem is that restrictivists either assert something self-contradictory, or are simply unable to assert their position at all (\$II). One might be inclined to conclude that absolutely unrestricted quantification must be possible. But this overlooks the possibility of dadaism. Dadists do not assert any position at all; they are militant quietists, who issue a combative challenge against generalists who seek to quantify 'absolutely unrestrictedly' (\$III). Indeed, dadaists aim to silence everyone who attempts to hold a positive doctrine about 'absolute generality' (\$IV). Whatever its drawbacks may be, dadaism is neither self-contradictory nor self-stultifying: it is a coherent version of restrictivism.

\section{I}

Consider the following principle:[

The Totality Principle. Any true sentence that uses a quantifier must quantify over some totality.

Why is this plausible? Just because, since Tarksi, this has been the standard treatment of quantified sentences. Here's another principle: $\$$

The Extendibility Principle. Given any totality of objects, we can find some object which is not in that totality.

\footnotetext{
${ }^{1}$ cf. Cantor's Domain Principle, as defended by Priest (2002, pp. 124-6, 280-2), and the All-in-One Principle, as attacked by Cartwright (1994).

${ }^{2}$ cf. Dummett on indefinite extensibility (e.g. 1963, p. 196; 1991, p.319; 1993a, p. 76; 1993b, pp. 441, 443).
} 
Why is this plausible? Well, given any totality, $T$, form the set of all those sets in $T$ which do not contain themselves. By Russell's paradox, this set was not among the original objects in $T$.

I shall not offer any serious defence of these two Principles in this paper. Instead, I want to start by asking whether they can be held simultaneously. This is worth investigating since, together, they yield an interesting argument.

Suppose you produce a sentence, $s$, that contains quantifiers. By the Totality Principle, there is some totality that $s$ quantifies over. By the Extendibility Principle, we can find some object which is not in that totality. So there is some object which $s$ did not quantify over. Since $s$ was an arbitrary sentence, we can confidently announce the following challenge:

The Challenge. You won't ever manage to produce a sentence that quantifies over everything!

Call someone who issues this challenge a restrictivist.

\section{II}

Some authors-for example, Lewis (1991, p. 62), Williamson (2003, pp. 427-8) and Lavine (2006, p. 102) - take restrictivists to go beyond issuing this challenge. They think that restrictivists assert a positive claim, namely:

The Doctrine. For any sentence $s, s$ does not quantify over everything.

And, admittedly, this Doctrine seems to be equally justified by the preceding argument from the two Principles. I shall call anyone who accepts this Doctrine a doctrinal restrictivist.

Unfortunately—as Lewis, Williamson, Lavine and others have noted-such doctrinal restrictivism is deeply problematic. Since the Doctrine is itself a sentence, we can substitute it into itself, obtaining:

(1) The Doctrine does not quantify over everything.

But since the Doctrine says precisely that no sentence can quantify over everything, we can say that:

(2) The Doctrine quantifies over everything.

And now the doctrinal restrictivist has contradicted herself.

Note that it does not help to argue that the occurrence of 'everything' in the Doctrine is to be read restrictively (that is, as only including some things, rather than absolutely everything). Whichever totality the Doctrine does quantify over-no matter how restrictedly we are to read the word 'everything' in the Doctrine-we ought to read (I) and (2) as quantifying over exactly that totality. Contradiction ensues on all precisifications of 'everything', and doctrinal restrictivism seems straightforwardly inconsistent.

In response to the charge of inconsistency, doctrinal restrictivists might argue that the Doctrine's quantified expression 'for any sentence $s$ ' is self-excepting; 
that is, that it quantifies over all sentences other than the Doctrine itself. Then (11) is not entailed by the Doctrine (at least, not by universal instantiation), and so no contradiction can be derived (at least, not immediately).

For now, let's allow that self-exception is not a cardinal sin. Nonetheless, an obvious problem remains. Even if doctrinal restrictivists don't have to assert (II), they still have to assert (2). But (2) straightforwardly entails:

(3) Some sentence quantifies over everything.

This seems fairly upsetting, by itself, for a doctrinal restrictivist.

To draw the sting, the doctrinal restrictivist should point out that we can instantiate the Doctrine with sentence (3), obtaining:

(4) Sentence (3) does not quantify over everything.

The doctrinal restrictivist can now argue that, when (3) claims that some sentence quantifies over 'everything', it doesn't say that any sentence quantifies over absolutely everything. On the contrary: (4) shows us that (3) really asserts something restricted. Hence, the doctrinal restrictivist will conclude, (3) need not upset her in the slightest.

The key move in this response is that the Doctrine is only self-excepting. Bearing this in mind, consider a sentence which attempts to express the (selfexcepting) content of the Doctrine in other words:

(5) No sentence (other than the Doctrine) quantifies over everything.

Perhaps, again, we should allow (5) to be self-excepting. However, (5) is distinct from the Doctrine, so we can merrily instantiate the Doctrine with (5), obtaining:

(6) Sentence (5) does not quantify over everything.

Now, reasoning as before, (6) shows us that (5) really asserts something restricted. In which case, (5) doesn't express the (self-excepting) content of the Doctrine. Indeed, it doesn't even get close: (6) presumably quantifies over everything that (5) quantifies over, and so witnesses that (5) just says something straightforwardly false.

The apparent upshot of all this is that no sentence other than the Doctrine itself can express the Doctrine's content. In which case, we can't talk about the Doctrine at all. (-'Since any such sentence will quantify restrictedly, relative to the Doctrine?' - No, we cannot even say that!) In such a situation, it is extremely odd to think that the Doctrine expresses anything at all, much less a proposition whose content we could learn or communicate to others. Doctrinal restrictivism may avoid inconsistency, but if it does so, it is utterly selfstultifying.

\footnotetext{
${ }^{3}$ I am here setting aside dialethean 'solutions' to the doctrinal restrictivist's predicament.
} 


\section{III}

The preceding argument shows that doctrinal restrictivism is either self-contradictory or self-stultifing. But we cannot conclude from this that generalism is true; that is, we cannot conclude that we can quantify absolutely unrestrictedly. Instead, we ought to reconceive restrictivism. Restrictivism should not be thought of as a positive doctrine, but rather as a form of militant quietism. In this section, I shall explain what this means, by drawing two analogies.

My first analogy is between restrictivism and Protagorean relativism. (To be clear, though, I don't wish to suggest anything here about the historical Protagoras; I just want to make some suggestions about a position that is Protagorean.) Protagorean relativists sometimes seemed to advocate the doctrine that there are no absolute truths, which prompted critics such as Plato (Theaetetus, 170a-171c) to ask:

- Is the doctrine that there are no absolute truths an absolute truth?

I contend that Protagorean relativists should not be embarrassed by this question. The question arises only if we treat Protagorean relativism as the positive doctrine that there are no absolute truths. It should instead be treated as a challenge to the absolutist: Give me something which you think is an absolute truth; engage with me in conversation for a while; and by the time you leave, I will have convinced you that your putative 'absolute truth' is-by your own lights-thoroughly relative. You defeat this Protagorean relativist not by showing that some positive doctrine is self-stultifying, but by showing why some specific sentence is absolutely true after all.

I do not wish to defend Protagorean relativism here; I simply want to employ the Protagorean's defensive strategy. Restrictivists sometimes seem to advocate a Doctrine, which prompts critics to ask:

- Does the Doctrine that nothing quantifies absolutely generally quantify absolutely generally?

This question is problematic if and only if restrictivism is treated as a positive doctrine. To be sure, any positive doctrine of restrictivism is self-stultifying: that's what the question shows, for it leads directly to the problems discussed in \$II. But the restrictivist should not be embarrassed by this. Restrictivists should simply issue a Challenge to their opponents (as originally suggested in SII) without ever falling into the trap of drawing a positive conclusion about 'absolute generality' (such as the Doctrine). The restrictivist should simply pick a fight: Give me a sentence which you think quantifies over absolutely everything; engage with me in conversation for a while; and by the time you leave, I will have convinced you that you failed-by your own lights-to quantify over absolutely everything. You defeat this restrictivist not by showing that some positive doctrine

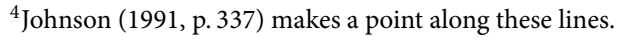


is self-stultifying, but by showing why some specific sentence quantifies over absolutely everything after all. ${ }^{\text {. }}$

Bearing this in mind, it is worth asking what role (if any) the Doctrine has to play in restrictivism. To answer this question, it will help to draw a second analogy; this time, with Feyerabendian irrationalism. ${ }^{0}$

Feyerabend once wrote, with his tongue firmly in his cheek, that 'there is only one principle that can be defended under all circumstances and in all stages of human development. It is the principle: anything goes' (1975, p. 28). This seemed to amount to the advocation of some principle, which prompted critics such as Putnam (1981, pp. 113-26) to ask, in effect:

- Does 'anything go' with regard to the principle anything goes?

This barbed question was not one that Feyerabend felt he needed to address, since (he claimed) it misunderstood his stance:

I... occasionally wrote in a rather ironical vein... 'anything goes' is not a 'principle' I hold... but the terrified exclamation of a rationalist who takes a closer look at history (1993, p. vii).

Again, my aim is not to defend Feyerabendian irrationalism; I simply want to employ Feyerabend's explanatory strategy. The restrictivist should explain the role of the Doctrine as follows:

I occasionally spoke in a rather ironical vein. The Doctrine is not a 'principle' I hold, but the terrified exclamation of a generalist who takes a closer look at the Two Principles.

In short, Protagoreans on 'absolute truth', Feyerabendians on 'rationality', and now restrictivists on 'absolute generality', should all be seen as simply challenging their opponents. If they ever seem to go beyond this challenge, they ought to do so only in 'a rather ironical vein'. In homage to Feyerabend (1975, p. 21,33), I shall call such 'ironical' restrictivists dadaists. (Those restrictivists who foolishly adhere to their Doctrine without irony will retain the name doctrinal restrictivists.)

To be clear, then: the dadaist never (sincerely) does anything more than challenge her generalist opponents to one-on-one arguments. Generalists will be 'apt to call this an argumentum ad hominem,' but what of it? Argumentum ad hominem is the right method of argumentation here. Dadaists-like relativists and irrationalists—are 'addressing humans, not... dogs' (Feyerabend 1975, pp. 113-4).

\section{IV}

We have seen the rough shape that dadaism will have to take: it must content itself with issuing challenges, and refrain from drawing positive conclusions.

\footnotetext{
${ }^{5}$ When I presented this paper at the 2009 Joint Session, other helpful analogies were suggested to me by Daniel Hill, Brian King and Richard Pettigrew. These included: (i) Apophaticists, who 'think' that we cannot speak about God; (ii) Kantians, who 'think' that we cannot speak about noumena; and (iii) Pyrrhonians, who 'think' that we cannot know anything. In all three cases, one might distinguish a doctrine from a challenge (hence the scare-quotes around 'think'). Space does not permit it here, but I hope to be able to explore these (and other) connections elsewhere.

${ }^{6}$ Feyerabend (1993, pp. 226, 268-9) connects his own irrationalism with Protagorean relativism.
} 
We should now explore dadaism in a little more detail. To do so, it will help to consider two objections that a generalist might raise against dadaism. Neither objection is successful, but responding to them helps to illustrate just how deep dadaism goes.

First Objection. The dadaist was led to issue her Challenge by invoking the two Principles. But these Principles themselves require absolutely unrestricted quantification. For example: the Extendibility Principle quantifies universally over all totalities, and it had better quantify over absolutely all of them if her Challenge is to have any bite. But that is surely just to quantify over everything (albeit, partioned up among the totalities). So the dadaist herself depends upon absolutely unrestricted quantification.

This objection certainly poses a problem for the doctrinal restrictivist. After all, the doctrinal restrictivist wants to assert the Doctrine on the basis of the truth of the two Principles. So this objection supplements the arguments of s[1, by showing once again that doctrinal restrictivism is self-stultifying.

However, this objection raises no problems for the dadaist. The dadaist need not assert the Extendibility Principle, nor the Totality Principle, 'with absolute generality' (so to speak). For the purposes of her Challenge, all she needs to do is to convince you, the generalist, that the sentence $s$, which you thought quantified over 'absolutely everything', actually does not. She only needs to convince you that there is some object that $s$ fails to quantify over, for the particular $s$ that you gave her. So the dadaist is free to reply to the First Objection as follows:

First Reply. I do not speak of the two Principles because I believe in them. Using a reductio ad absurdum does not commit the arguer to accepting the premises. 1

However, this reply is very slightly imprecise, and its imprecision is likely to provoke a rather more interesting objection from the generalist:

Second Objection. The dadaist just admitted that she uses the two Principles in a reductio ad $a b$ surdum. In this, she is surely right: the Doctrine leads to a straightforward logical contradiction, in the form of sentences (II) and (2). In that case, we can classically derive the Doctrine's negation, namely, sentence (3). But the dadaist surely does not want to assert (3)!

This objection again misunderstands dadaism. In fact, the dadaist can allow anyone who wants to to assert (3), for the dadaist maintains that (3) can bring joy to the generalist. But this requires some explanation.

Suppose the generalist asserts (3), and understands it according to the Totality Principle. Then all he has succeeded in saying, by his own lights, is that some sentence quantifies over everything-that-(3)-quantifies-over. This is perfectly true; after all, on this understanding of (3), sentence (3) is itself a perfectly good witness to its own truth. But equally, on this understanding, sentence (3) clearly does not express the generalist's thesis. It expresses little more than the innocuous claim: sometimes I use the universal quantifier

What's more, the dadaist thinks that she can convince the generalist that sentence (3) cannot mean what the generalist wants it to mean. Let's grant, for

\footnotetext{
${ }^{7}$ Our dadaist is paraphrasing Feyerabend (1987, p. 283): 'Nor do I speak of progress because I believe in it or pretend to know what it means (using a reductio ad absurdum does not commit the arguer to accepting the premises).'
} 
now, that the dadaist is very good at arguing with her opponents (I shall come back to this assumption in \$VD). That is, whenever the dadaist meets someone who calls himself a generalist, and who says 'I can quantify absolutely unrestrictedly', our dadaist can show the generalist that those words do not mean what the generalist wanted them to mean. To be able to do this, the dadaist does not need to claim to understand what the generalist wants those words to mean. All the dadaist needs to know is that her generalist interlocutor has become upset during the course of conversation. The dadaist can determine this fact on behavioural grounds alone (by the generalist's weeping, gnashing of teeth, etc.).

If this happens often enough, the dadaist is likely to conclude that any attempt to state a positive doctrine of generalism inevitably fails in its ambitions. Of course, our dadaist thinks that any positive doctrine of restrictivism fails too: she paid attention during $\$$ 佃 of this paper, and thoroughly endorses the conclusion that doctrinal restrictivism is self-stultifying. Our dadaist therefore thinks that any putative positive doctrine whatsoever about 'unrestricted quantification' fails in its ambitions, whether that doctrine is generalist or restrictivist.

Putting all this together, then, the dadaist ought to clarify her imprecise First Reply with a second, more careful, speech:

Second Reply. When I argue with my opponents, I do not speak of 'absolute generality' because I believe in it or pretend to know what it means. On the contrary, I want to show that talking about 'absolute generality' is nonsense.

Strictly speaking, then, this is not to engage in a reductio ad absurdum. To engage in a reductio, I would have to start by assuming that some sentence is true, and proceed to derive its negation. In fact, I start by pretending that some sentence makes sense (some sentence containing the phrase 'absolute generality' or 'absolutely everything'), and I then produce a series of sounds which might seem, to my opponent, like a logical argument leading towards a contradiction.

Now, when I do this, I do not think that I am giving a logical argument. On the contrary, many of the sentences that I utter along the way are sheer nonsense, and I am well aware that putting logical connectives between nonsense yields not a logical argument, but just more complicated nonsense.

My opponents, by contrast, believe that 'absolute generality' makes sense. And, so long as they believe this, they are compelled to treat the sounds I make as constituting an argument (in the most straightforward sense). In so doing-and I know this from past experience-my opponents become completely tangled up in knotty paradoxes, and they can't explain themselves. Sometimes, this feeling of aporia helps them to see that what they had been trying to say was nonsensical garbage; other times, they simply can't be helped out of their muddle. But, however they react, the Second Objection does not affect me at all. The reason for this is straightforward: pretending that some phrase makes sense-in order to show that it does not-does not commit me to accepting that the phrase does make sense $\mathbb{B}$

By their own admission, then, dadaists (sometimes) spout nonsense. But, unlike the nonsense of doctrinal restrictivism, it is not self-stultifying nonsense. Rather, it is nonsense that stultifies every putative positive doctrine about 'absolute generality'. Since the dadaist holds no such doctrine, she has nothing to fear from her own nonsense.

${ }^{8}$ cf. Feyerabend's (1987, p. 283) quip quoted in the previous footnote, and Feyerabend's reply to Putnam. When Putnam says that 'our grasp on what the [relativist] position even means begins to wobble' (1981, p. 121), Feyerabend shoots back 'It certainly does-but only if the "position" is read as an objective account of knowledge. A rhetorical account that addresses objectivists with the intention of confusing them is already talking to the right party' (1987, p. 83). 
It should now be clear why dadaism amounts to militant quietism. Dadaists seek to force everyone into silence on the matter of 'absolutely unrestricted' quantification. Such a quietist position is surely coherent, and that is all I have attempted to show in this short paper.

For all that, dadaism might well be wrong. Everything depends on whether dadaists are any good at arguing with their opponents. Dadaism flounders if and only if someone can answer the dadaist Challenge of s[ on its own terms. You must try to produce a sentence which seems like it quantifies over everything. The dadaist will run an argument to show you why your sentence does not do what you wanted it to do (whatever that may have been). If you can block the dadaist's argument, then victory is yours. But there is no quick proof of generalism from the failure of doctrinal restrictivism, for dadaism is a coherent version of-or, perhaps better, heir to-restrictivism.

\section{References}

Cartwright, Richard (1994). "Speaking of Everything". Noûs, 28, pp. 1-20.

Dummetт, Michael (1963). “The Philosophical Significance of Gödel's Theorem". In Truth and Other Enigmas (1978). London: Duckworth, pp. 186-214.

Dummett, Michael (1991). Frege: Philosophy of Mathematics. London: Duckworth.

Dummett, Michael (1993a). “Introductory Remarks". In Czermak, J, editor: Proceedings of the International Wittgenstein Symposium. Volume 15, Vienna: Hölder-Pichler-Tempsky, pp. 69-76.

Dummetт, Michael (1993b). "What is Mathematics About?" In The Seas of Language. Oxford: Oxford University Press, pp. 429-445.

Feyerabend, Paul (1975). Against Method: Outline of an anarchist theory of knowledge. 1st edition. London: Verso.

Feyerabend, Paul (1987). Farewell to Reason. 2nd edition. London: Verso.

Feyerabend, Paul (1993). Against Method. 3rd edition. London: Verso.

Johnson, Jeffery L (1991). "Making Noises in Counterpoint or Chorus: Putnam's Rejection of Relativism”. Erkenntnis, 34.3, pp. 323-45.

LAVINE, Shaughan (2006). "Something About Everything: Universal Quantification in the Universal Sense of Universal Quantification". In Rayo, Agustín and UzQuiano, Gabriel, editors: Absolute Generality. Oxford: Oxford University Press, pp. 98-148.

Lewis, David (1991). Parts of Classes. Oxford: Basil Blackwell.

Priest, Graham (2002). Beyond the Limits of Thought. 2nd edition. Oxford: Oxford University Press.

\footnotetext{
${ }^{9}$ For conversations about various versions of this paper, I'd like to thank: Matti Eklund, Daniel Hill, Brian King, Jon Litland, Charles Parsons, Richard Pettigrew, Michael Potter, Peter Smith and Timothy Williamson.
} 
Putnam, Hilary (1981). Reason, Truth and History. Cambridge: Cambridge University Press.

Williamson, Timothy (2003). "Everything". In Hawthorne, John and Zimmerman, Dean, editors: Noûs: Philosophical Perspectives. Volume 17, Oxford: Blackwell, pp. 415-465. 